\title{
A $\beta$ Inhibition of Ionic Conductance in Mouse Basal Forebrain Neurons Is Dependent upon the Cellular Prion Protein $\operatorname{PrP}^{\mathrm{C}}$
}

\author{
Kwai Alier, ${ }^{1 \star}$ Li Ma, ${ }^{1 *}$ Jing Yang, ${ }^{2}$ David Westaway,,${ }^{1,2}$ and Jack H. Jhamandas ${ }^{1}$ \\ ${ }^{1}$ Department of Medicine (Neurology), University of Alberta, Edmonton, Alberta T6G 2S2, Canada, and ${ }^{2}$ Centre for Prions and Protein Folding Diseases, \\ University of Alberta, Edmonton, Alberta T6G 2M8 Canada
}

Current therapies for Alzheimer's disease (AD) address a loss of cholinergic neurons, while accumulation of neurotoxic amyloid $\beta(\mathrm{A} \beta)$ peptide assemblies is thought central to molecular pathogenesis. Overlaps may exist between prionopathies and AD wherein A $\beta$ oligomers bind to the cellular prion protein $\operatorname{PrP}^{\mathrm{C}}$ and inhibit synaptic plasticity in the hippocampus (Laurén et al., 2009). Here we applied oligomeric $\mathrm{A} \beta$ to neurons with different $\operatorname{PrP}(\operatorname{Prn} p)$ gene dosage. Whole-cell recordings were obtained from dissociated neurons of the diagonal band of Broca (DBB), a cholinergic basal forebrain nucleus. In wild-type (wt) mice, $\mathrm{A} \beta_{1-42}$ evoked a concentration-dependent reduction of whole-cell outward currents in a voltage range between -30 and $+30 \mathrm{mV}$; reduction occurred through a combined modulation of a suite of potassium conductances including the delayed rectifier $\left(I_{\mathrm{K}}\right)$, the transient outward $\left(I_{\mathrm{A}}\right)$, and the iberiotoxin-sensitive (calcium-activated potassium, $I_{\mathrm{C}}$ ) currents. Inhibition was not seen with $\mathrm{A} \beta_{42-1}$ peptide, while $\mathrm{A} \beta_{1-42}$-induced responses were reduced by application of anti-PrP antibody, attenuated in cells from $\operatorname{Prnp}^{0 /+}$ hemizygotes, and absent in $\operatorname{Prnp} p^{0 / 0}$ homozygotes. Similarly, amyloidogenic amylin peptide depressed DBB whole-cell currents in DBB cells from wt mice, but not Prnp ${ }^{0 / 0}$ homozygotes. While prior studies give broad support for a neuroprotective function for $\operatorname{PrP}^{\mathrm{C}}$, our data define a latent pro-pathogenic role in the presence of amyloid assemblies.

\section{Introduction}

Alzheimer's disease $(\mathrm{AD})$ is the most common neurodegenerative disease and is characterized by loss of cognitive function leading to frank dementia. Amyloid $\beta(\mathrm{A} \beta)$, a secreted peptide cleavage product of amyloid precursor protein (APP), is thought to be important in mediating synaptic disruption, neuronal dysfunction, and cell death (Walsh et al., 2002; Palop and Mucke, 2010). Intermediate-sized, soluble assemblies of $A \beta$ are implicated in synaptotoxicity more so than large fibrillar assemblies or plaques (Bitan et al., 2003; Kirkitadze and Kowalska, 2005; Teplow et al., 2006). For prion diseases, the cellular prion protein $\mathrm{PrP}^{\mathrm{C}}$ precursor, encoded by the Prnp gene, is a membraneanchored glycoprotein that is remodeled to a $\beta$-sheet-enriched

\footnotetext{
Received Aug. 25, 2011; revised Sept. 19, 2011; accepted Sept. 21, 2011

Author contributions: K.A., D.W., and J.H.J. designed research; K.A., L.M., and J.Y. performed research; J.Y., D.W., and J.H.J. contributed unpublished reagents/analytic tools; K.A., L.M., J.Y., D.W., and J.H.J. analyzed data; K.A., L.M., D.W., and J.H.J. wrote the paper.

This research was supported by grants from the Alberta Prion Research Institute, the Alberta Ingenuity Fund, the PrioNet Network Centre of Excellence, and the Canadian Institutes of Health Research. We thank David MacTavish and Beipei Shi for technical assistance.

*K.A. and L.M. contributed equally to this work.

The authors declare no competing financial interests.

Correspondence should be addressed to either of the following: Dr. Jack H. Jhamandas, 530 Heritage Medical Research Centre, Department of Medicine (Neurology), University of Alberta, Edmonton, AB T6G 2S2, Canada, E-mail: jack.jhamandas@ualberta.ca; or Dr. David Westaway, Centre for Prions and Protein Folding Diseases, 204 Environmental Engineering Building, University of Alberta, Edmonton, AB T6G 2M8, Canada, E-mail: david.westaway@ualberta.ca.

DOI:10.1523/JNEUROSCI.4367-11.2011

Copyright $\odot 2011$ the authors $\quad 0270-6474 / 11 / 3116292-06 \$ 15.00 / 0$
}

isoform, $\operatorname{PrP}^{\mathrm{Sc}}$ (Prusiner, 1991). Recently, soluble forms of $\mathrm{A} \beta$ have been reported to bind $\operatorname{PrP}^{\mathrm{C}}$, resulting in suppression of synaptic plasticity in hippocampal slices (Laurén et al., 2009). Further, transgenic ( $\mathrm{Tg}$ ) mice expressing familial AD-associated mutant forms of $\beta$ APP (TgAPP mice) are rescued from memory impairment and early death following ablation of $\operatorname{PrP}^{\mathrm{C}}$ (Gimbel et al., 2010). While some other studies are in broad accord with these notions (Barry et al., 2011; Freir et al., 2011), others have disputed an obligatory role for $\operatorname{PrP}^{\mathrm{C}}$ in $\mathrm{A} \beta$-induced impairment of synaptic structure and function, and in $\mathrm{AD}$-related behavioral endpoints (Balducci et al., 2010; Calella et al., 2010; Kessels et al., 2010; Cissé et al., 2011) yet have confirmed physical interactions between A $\beta$ and PrP (Balducci et al., 2010; Chen et al., 2010; Bate and Williams, 2011). We investigated this provocative area. Our prior studies have defined neuronal excitability-modifying properties of PrP (Alier et al., 2010) focusing on the 105-125 region (mouse PrP numbering) immediately adjacent to a putative 95$105 \mathrm{~A} \beta$ binding site. Here we measured the actions of oligomeric $\mathrm{A} \beta$ and human amylin-another amyloidogenic peptide that shares some biophysical and neurotoxic properties with $\mathrm{A} \beta$ - on forebrain neurons from the nucleus of the diagonal band of Broca (DBB). Using mice of different Prnp genotypes, our data implicate a requirement for $\operatorname{PrP}^{\mathrm{C}}$ in $\mathrm{A} \beta$ and amylin depression of specific potassium conductances.

\section{Materials and Methods}

Mouse strains. All procedures were complied with Canadian Council for Animal Care guidelines. Congenic Prnp ${ }^{0 /+}$ mice (Zrch 1 allele, 17 back- 
crosses to C57BL/6 stock, Taconic) were intercrossed to yield Prnp ${ }^{0 / 0}$, $\operatorname{Prnp}{ }^{0 /+}$, and wild-type (wt) genotypes (of either sex), with additional wt mice purchased for some experiments (Taconic Farms, "C57BL/6Tac"). (Janus et al., 2000; Chishti et al., 2001).

Acutely dissociated cells and whole-cell recordings. These procedures were as described previously (Jhamandas et al., 2001, 2011). Data are presented as mean \pm SE. Student's two-tailed $t$ test (paired when appropriate) was used for determining significance of effect in electrophysiological measurements.

Reagents. Oligomeric form of $\mathrm{A} \beta_{1-42}$ peptide (rPeptide), $\mathrm{A} \beta_{42-1}$, and human amylin (American Peptide) were prepared as described previously (Stine et al., 2003, 2011; Jhamandas et al., 2011). Peptides were diluted in external perfusion medium just before application. PrP antibody Sha31 (Medicorp) was diluted to a concentration of $300 \mathrm{ng} / \mathrm{ml}$ before use. All drugs and chemicals were applied via bath perfusion (3-5 $\mathrm{ml} / \mathrm{min}$ ), which allowed complete exchange in less than half a minute.

\section{Results}

\section{Recordings from DBB neurons}

Dissociated neurons from the DBB contain a variety of potassium conductances: transient outward $\left(I_{\mathrm{A}}\right)$, delayed rectifier $\left(I_{\mathrm{K}}\right)$, and calcium-activated potassium $\left(I_{\mathrm{C}}\right)$. The effect of $\mathrm{A} \beta$ on this ionic conductance was investigated in mice of different Prnp genotypes. Average membrane capacitance $\left(C_{\mathrm{m}}\right)$ was estimated on an Axopatch-1D amplifier: wt mice had a $C_{\mathrm{m}}$ of $8.75 \pm 0.59 \mathrm{pF}(n=$ 8; C57BL/6) or $9.75 \pm 0.56 \mathrm{pF}(n=10$; C57BL/6Tac), while $\operatorname{Prnp}^{0 /+}$ mice and Prnp ${ }^{0 / 0}$ mice had $C_{\mathrm{m}}$ values of $12 \pm 0.76 \mathrm{pF}$ $(n=9)$ and $8 \pm 0.60 \mathrm{pF}(n=10)$, respectively. Under control conditions without drug, the average input conductance measured from the slope of the current-voltage $(I-V)$ relationships between -60 and $-110 \mathrm{mV}$ was $1.05 \pm 0.22 \mathrm{nS}(\mathrm{C} 57 \mathrm{BL} / 6)$, $0.93 \pm 0.12 \mathrm{nS}(\mathrm{C} 57 \mathrm{BL} / 6 \mathrm{Tac}), 0.93 \pm 0.19 \mathrm{nS}\left(\operatorname{Prnp}^{0 /+}\right)$, and $0.77 \pm 0.18 \mathrm{nS}\left(\operatorname{Prnp}^{0 / 0}\right)$. Application of $1 \mu \mathrm{M}$ oligomeric $\mathrm{A} \beta_{1-42}$ (Stine et al., 2003, 2011) had no significant effect on conductance in this voltage range compared to that under control conditions $(1.34 \pm 0.22 \mathrm{nS}, p>0.05, n=8, \mathrm{C} 57 \mathrm{BL} / 6 ; 0.94 \pm 0.13 \mathrm{nS}, p>$ $0.05, n=10$, C57 BL/6Tac; $0.91 \pm 0.13 \mathrm{nS}, p>0.05, n=9$, $\left.\operatorname{Prnp}^{0 /+} ; 1.07 \pm 0.28 \mathrm{nS}, p>0.05, n=10, \operatorname{Prnp}^{0 / 0}\right)$.

\section{Effects of oligomeric $A \boldsymbol{\beta}_{1-42}$ on the whole-cell currents}

Whole-cell currents (WCC) were investigated in $\operatorname{Prnp}{ }^{+/+}$, $\operatorname{Prnp}^{0 /+}$, and Prnp ${ }^{0 / 0}$ cells under control conditions and in the presence of $\mathrm{A} \beta_{1-42}(1 \mu \mathrm{M})$. $\mathrm{A} \beta_{1-42}$ inhibited whole-cell currents in the range -30 to $+30 \mathrm{mV}$. In $\mathrm{C} 57 \mathrm{BL} / 6 \mathrm{Tac}$ wt mice, $\mathrm{A} \beta_{1-42}$ significantly reduced WCC (control $=5.60 \pm 0.26 \mathrm{nA}, \mathrm{A} \beta_{1-42}=$ $4.84 \pm 0.28 \mathrm{nA}$ at $+30 \mathrm{mV},{ }^{\star} p<0.05, n=8$ ) (Fig. $\left.1 A\right)$. A $\beta_{1-42}$ inhibited peak whole-cell currents of DBB neurons in a dosedependent manner (Fig. $1 C$ ). Inverse $\mathrm{A} \beta, \mathrm{A} \beta_{42-1}$, peptide $(1 \mu \mathrm{M})$ had no effect on WCC (control $=4.76 \pm 0.51 \mathrm{nA}, \mathrm{A} \beta_{42-1}=$ $4.51 \pm 0.47 \mathrm{nA}$ at $+30 \mathrm{mV}, p=0.36, n=6$ ) (Fig. $1 B$ ). In the $\mathrm{C} 57 \mathrm{BL} / 6$ wt mice at $+30 \mathrm{mV}$, application of $\mathrm{A} \beta_{1-42}$ significantly decreased WCC from $3.72 \pm 0.27 \mathrm{nA}$ to $3.08 \pm 0.27 \mathrm{nA}$, a reduction of $15.21 \pm 1.2 \%,{ }^{*} p<0.05, n=8$ ) (Fig. $\left.2 A\right)$. A $\beta_{1-42}$ had no significant effect on the WCC of $\operatorname{Prnp}^{0 /+}$ mice (control $=3.94 \pm$ $0.27 \mathrm{nA}, \mathrm{A} \beta_{1-42}=3.63 \pm 0.26 \mathrm{nA}$ at $\left.+30 \mathrm{mV}, p=0.19, n=9\right)$ (Fig. $2 \mathrm{~B}$ ) and $\operatorname{Prnp}^{0 / 0}$ mice (control $=3.65 \pm 0.44 \mathrm{nA}, \mathrm{A} \beta_{1-42}=$ $3.57 \pm 0.42 \mathrm{nA}$ at $+30 \mathrm{mV}, p=0.41, n=10$ ) (Fig. $2 C$ ). We also investigated whether the anti- $\mathrm{PrP}^{\mathrm{c}}$ antibody (Sha31) is able to inhibit the $\mathrm{A} \beta_{1-42}$-evoked reduction of WCC on the DBB neurons in $\mathrm{PrnP}^{+/+}$mice. Seventy-five percent ( 6 of 8 cells) of DBB neurons responded to $A \beta_{1-42}$ in the usual manner. However, in the presence of anti-PrP ${ }^{\mathrm{C}}$ antibody Sha31, $\mathrm{A} \beta_{1-42}(1 \mu \mathrm{M})$-evoked depression of WCC in wt DBB neurons was markedly reduced, compared to control conditions (Fig. 2D).
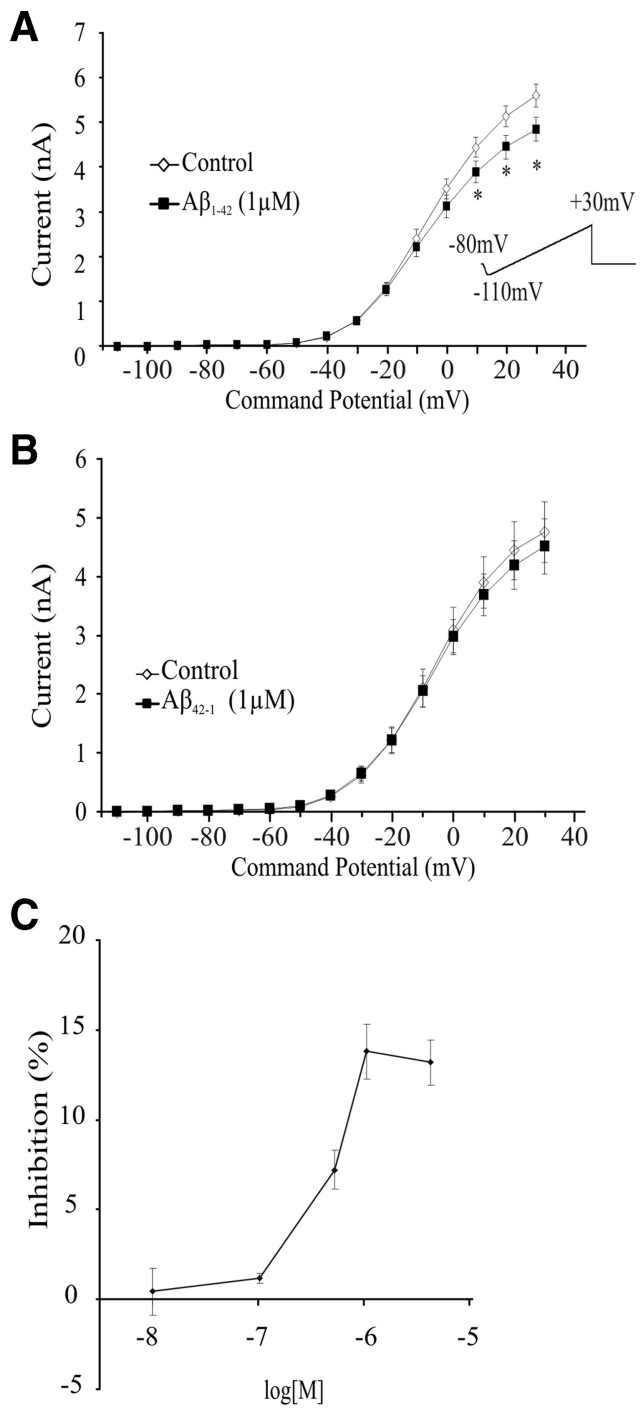

Figure 1. Effects of $A \beta_{1-42}$ on DBB WCC in wt mice. $A, A \beta_{1-42}(1 \mu \mathrm{m})$ significantly depresses WCC ( ${ }^{*} p<0.05, n=8$ at $\left.+30 \mathrm{mV}\right)$, inset shows the voltage ramp protocol applied for 10 s. $\boldsymbol{B}$, Reversed oligomers $A \beta_{42-1}(1 \mu \mathrm{m})$ peptide had no effect on WCC $(p=0.36 n=6$ at $+30 \mathrm{mV}$ ). C, Dose-response relationship for $A \beta_{1-42}$-evoked inhibition of peak WCC at +30 $\mathrm{mV}(n=5$ at each dose).

Outward potassium currents in DBB neurons are a mixture of calcium and non-calcium-activated components (Jhamandas et al., 2001). The non-calcium-activated component consists primarily of the $I_{\mathrm{K}}$ and the $I_{\mathrm{A}}$ currents, while the calcium-dependent component of potassium currents includes voltage-sensitive conductances, $I_{\mathrm{C}}$ (BK channels). The effects of oligomeric $\mathrm{A} \beta_{1-42}$ on these conductances were further investigated in wt (i.e., Prnp ${ }^{+/+}$) mice.

\section{Effects of $\mathrm{A} \boldsymbol{\beta}_{1-42}$ on $I_{\mathrm{A}}$ and the $I_{\mathrm{K}}$ potassium currents in wt mice}

Both $I_{\mathrm{A}}$ and $I_{\mathrm{K}}$ currents are voltage sensitive, and their activation and inactivation are strongly voltage dependent. $I_{\mathrm{A}}$ requires the holding potential to be relatively hyperpolarized (approximately $-110 \mathrm{mV}$ ) for removal of its inactivation, whereas it is inactivated at $-40 \mathrm{mV}$. On the other hand, $I_{\mathrm{K}}$ is not inactivated at -40 $\mathrm{mV}$. Hence, the difference in the biophysical properties of $I_{\mathrm{A}}$ and $I_{\mathrm{K}}$ was used to isolate these two currents. Application of a conditioning pulse to $-40 \mathrm{mV}$ will activate $I_{\mathrm{K}}$ without any significant 

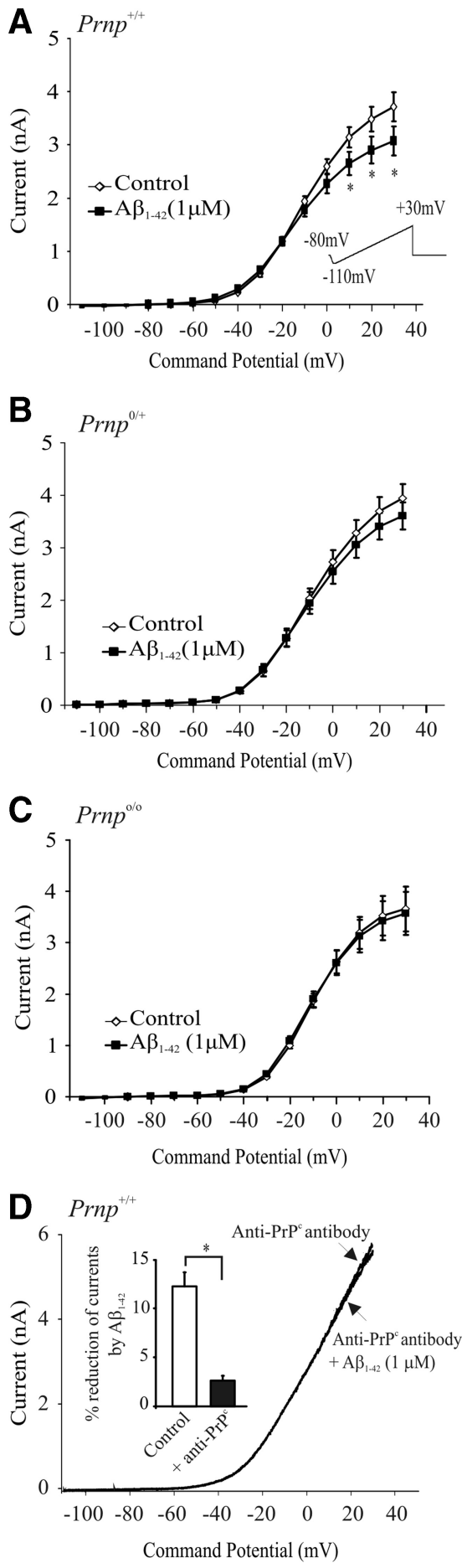

Figure 2. Effect of Prnp gene dosage and PrP blockade on $A \beta$ inhibition of DBB whole-cell currents. $A, A \beta_{1-42}$ significantly reduces WCC of DBB neurons from C57BL/6Tac wtmice ${ }^{*} p<0.05, n=$ 8 at $+30 \mathrm{mV})$. $\boldsymbol{B}$, Effects of $A \beta_{1-42}$ on DBB whole-cell currents of heterozygous $\left(\right.$ Prnp $\left.^{0 /+}\right)$ mice. Current-Voltage (I-V) plot of slight reduction in WCC following application of $A \beta_{1-42}(p>0.05$, $n=8$ at $+30 \mathrm{mV})$. C, Effects of $A \beta_{1-42}$ on DBB whole-cell currents of homozygous $\left(\right.$ Prnp ${ }^{0 / 0}$ ) mice. $I-V$ plot of slight reduction in WCC following application of $A \beta_{1-42}(p>0.05, n=10$ at $+30 \mathrm{mV})$. $D$, In the presence of anti-PrP antibody Sha31, $A \beta_{1-42}$ reduction of WCC in DBB neurons from wt mice is markedly blunted compared to control conditions (no antibody). Inset shows reduction of WCC by $\mathrm{A} \beta_{1-42}$ without and in the presence of the anti-PrP antibody Sha31 ( $p>0.001, n=9$ at $+30 \mathrm{mV}$ ).

contamination by $I_{\mathrm{A}}$ (Connor and Stevens, 1971). A conditioning pulse to $-120 \mathrm{mV}$ will activate both $I_{\mathrm{A}}$ and $I_{\mathrm{K}}$. Difference currents obtained by subtracting the currents evoked by depolarizing pulses following a conditioning pulse to $-40 \mathrm{mV}$ from those evoked following a conditioning pulse to $-120 \mathrm{mV}$ provide an estimate of $I_{\mathrm{A}}$. The currents were recorded from a neuron with a conditioning pulse to $-40 \mathrm{mV}$ for $150 \mathrm{~ms}$, representing mainly $I_{\mathrm{K}}$, under control conditions, and in the presence of oligomeric $\mathrm{A} \beta_{1-42}(1 \mu \mathrm{M}) . \mathrm{A} \beta_{1-42}$ reduced $I_{\mathrm{K}}$ by $20.08 \pm 1.86 \%$ compared to the control (control $=4.82 \pm 0.29 \mathrm{nA}, \mathrm{A} \beta_{1-42}=3.66 \pm 0.18 \mathrm{nA}$, at $+30 \mathrm{mV}, p<0.05, n=5$ ) (Fig. $3 A$ ). Figure $2 B$ shows difference currents recorded from the same neuron representing mainly $I_{\mathrm{A}}$, under control conditions, and in the presence of $\mathrm{A} \beta_{1-42} . \mathrm{A} \beta_{1-42}$ significantly reduced $I_{\mathrm{A}}$ by $20.4 \pm 4.6 \%$ compared to control (control $=1.90 \pm 0.10 \mathrm{nA}, \mathrm{A} \beta_{1-42}=1.44 \pm 0.10 \mathrm{nA}$, at $+30 \mathrm{mV}$, $p<0.05, n=4)$.

\section{Effects of $A \boldsymbol{\beta}_{1-42}$ oligomers on calcium-activated potassium currents in wt mice}

Calcium-activated currents include the voltage-sensitive conductances called maxi $g \mathrm{~K}(\mathrm{Ca})\left(I_{\mathrm{C}}\right.$ or $\left.\mathrm{BK}\right)$ and the voltage-insensitive ones that underlie action potential afterhyperpolarization $\left(I_{\mathrm{AHP}}\right)$. Of the two main $\mathrm{Ca}^{2+}$-activated potassium currents, under whole-cell recording conditions from DBB neurons, the apaminsensitive slow $I_{\mathrm{AHP}}(\mathrm{SK})$ makes little contribution, and the majority of the currents flow through $I_{\mathrm{C}}$ channels (Jhamandas et al., 2001). Indeed, as in rat DBB neurons (Jassar et al., 1999), we observed no apamin-sensitive currents in DBB cells from C57BL/ $6 \mathrm{Tac}$ wt mice (data not shown). To determine the degree to which $\mathrm{A} \beta_{1-42}$ oligomer $(1 \mu \mathrm{M})$ effects are mediated via $I_{\mathrm{C}}$, we examined actions of $\mathrm{A} \beta_{1-42}$ under conditions where cells from C57BL/6Tac mice were perfused with iberiotoxin (IBTX), a specific blocker of $I_{\mathrm{C}}$ channels. Figure $3 C$ shows the average of current-voltage relationships obtained from six neurons under control conditions, in the presence of IBTX (50 nM) alone, and upon application $\mathrm{A} \beta_{1-42}$ in the presence of IBTX. IBTX applied alone reduced outward currents. Application of $\mathrm{A} \beta_{1-42}$ in the presence of IBTX resulted in an additional, but smaller, reduction of the currents than evoked by $\mathrm{A} \beta_{1-42}$ alone (control $=5.18 \pm 0.19 \mathrm{nA}, \mathrm{IBTX}=$ $4.55 \pm 0.25 \mathrm{nA}$, IBTX and $\mathrm{A} \beta_{1-42}=4.42 \pm 0.26 \mathrm{nA}$ at $+30 \mathrm{mV}$, ${ }^{*} p<0.05$ compared to control, $n=6$ ). Thus, $\mathrm{A} \beta$ effects on $I_{\mathrm{C}}$ type of $\mathrm{K}^{+}$channels contribute to the overall reduction in wholecell currents that is observed in peptide-treated DBB neurons.

\section{Human amylin peptide reduces whole-cell currents in wt DBB neurons}

Effects of human amylin on WCC were examined on DBB neurons from wt and $P r n p^{0 / 0}$ mice. Application of human amylin (1 $\mu \mathrm{M})$ in DBB neurons from C57BL/6Tac wt mice resulted in a significant reduction in WCC in the voltage range -30 to +30 $\mathrm{mV}$ (control $=6.83 \pm 0.0 .95 \mathrm{nA}$, human amylin $=5.77 \pm 0.78$ $\mathrm{nA}$ at $+30 \mathrm{mV},{ }^{\star} p<0.05, n=7$ ) (Fig. $4 A$ ). Human amylin had no significant effect on the WCC of $\operatorname{Prnp} p^{0 / 0}$ mice (control $=$ $5.02 \pm 0.40 \mathrm{nA}$, human amylin $=4.81 \pm 0.35 \mathrm{nA}$ at $+30 \mathrm{mV}, p=$ $0.7, n=5)$ (Fig. $4 B$, inset).

\section{Discussion}

Using $\mathrm{A} \beta_{1-42}$ multimeric assemblies_-visualized as spheroidal structures by electron microscopy (Jhamandas et al., 2005, 2011) — we have documented inhibition of a suite of potassium conductances, i.e., $I_{\mathrm{K}}, I_{\mathrm{A}}$, and $I_{\mathrm{C}}$. The effect was observed in dissociated neurons derived from the $\mathrm{DBB}$, a cholinergic forebrain nucleus (Jhamandas et al., 2001). In heterozygous mice, there was an insignificant suppression of whole-cell currents, while in the homozygous null $\operatorname{Prnp}^{0 / 0}$ mice, there was no suppression. To confirm that these effects upon $\mathrm{A} \beta_{1-42}$ action were mediated directly by $\operatorname{PrP}^{\mathrm{C}}$ protein, rather than reflecting a secondary ge- 
A
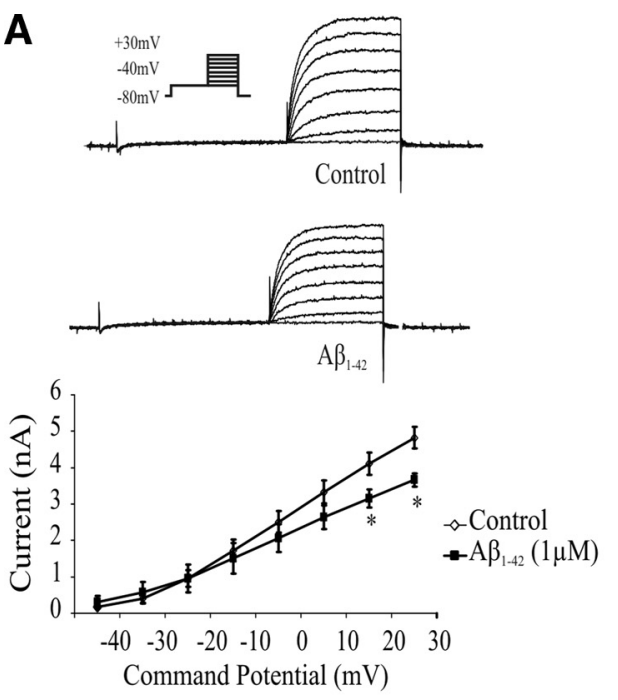

B
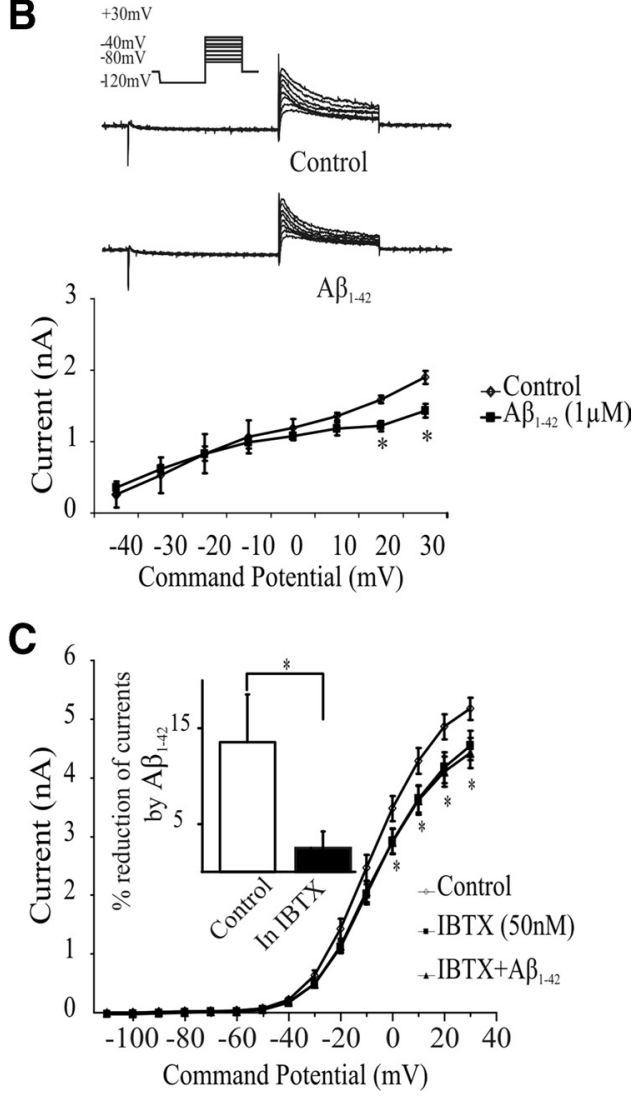

Figure 3. $A \beta_{1-42}$ significantly reduces the $I_{K^{\prime}} I_{A^{\prime}}$ and $I_{C}$ currents in DBB neurons. $A$, Voltage protocol for recording $I_{K}$ is depicted on the left with a holding potential of $-80 \mathrm{mV}$ and a $150 \mathrm{~ms}$ conditioning pulse to $-40 \mathrm{mV}$. Top, The effect of $A \beta_{1-42}$ on $I_{\mathrm{K}}$. Bottom, $I-V$ plot of the peak $I_{\mathrm{K}}$ current indicating a reduction of the $I_{K}$ current after 5 min perfusion of $A \beta_{1-42}(1 \mu \mathrm{M})\left(^{*} p<\right.$ $0.05, n=5$ at $+30 \mathrm{mV}) . \boldsymbol{B}$, Top, $I_{A}$ obtained as difference currents by subtracting the currents obtained by the voltage protocol in $\boldsymbol{A}$ from that obtained by applying the voltage protocol shown here (cells held at $-80 \mathrm{mV}$ and a conditioning $150 \mathrm{~ms}$ pulse applied to $-120 \mathrm{mV}$ ). Bottom, $I-V$ plot of the $I_{A}$ current indicating a reduction of the peak $I_{A}$ current after 5 min perfusion of $A \beta_{1-42}(1 \mu \mathrm{m})\left({ }^{*} p<0.05, n=4\right.$ at $\left.+30 \mathrm{mV}\right) . C, I-V$ relationship from DBB neurons under control conditions, in $50 \mathrm{~nm} \mathrm{IBTX,} \mathrm{in} 1 \mu \mathrm{M} \mathrm{A} \beta_{1-42}$ in IBTX ( ${ }^{*} p<0.05$ compared to control, $n=6$ at $+30 \mathrm{mV}$ ). Inset shows reduction of WCC under control conditions by $\mathrm{A} \beta_{1-42}$ and in the presence of the IBTX ( $p>0.05, n=6 \mathrm{at}+30 \mathrm{mV}$ ). All recordings were made from wt cells.

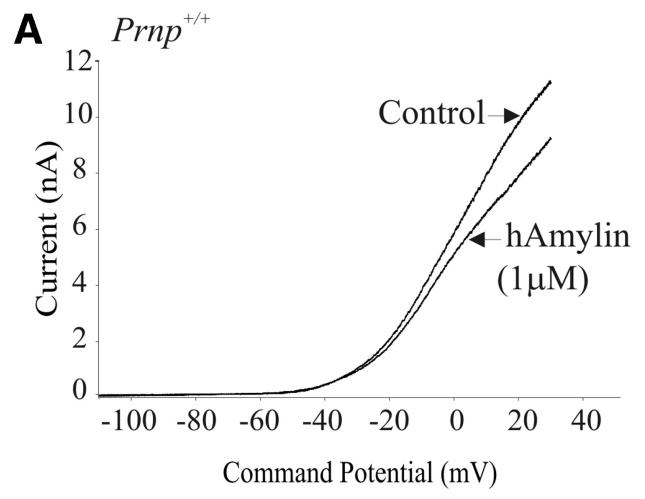

B $\quad \operatorname{Prnp}^{0 / 0}$

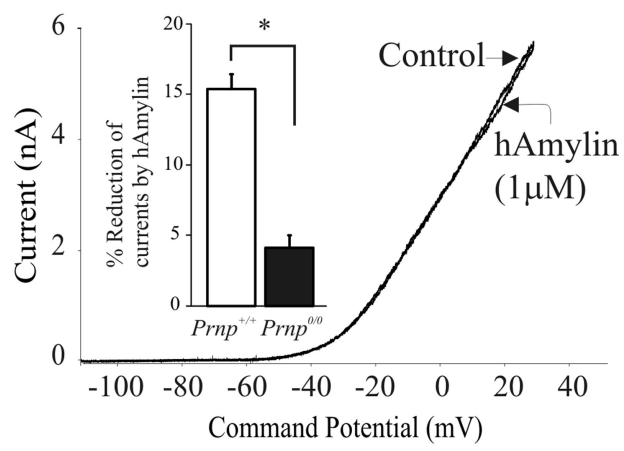

Figure 4. Effect of Prnp gene dosage on human amylin (hAmylin) inhibition of DBB wholecell currents. $\boldsymbol{A}$, hAmylin $(1 \mu \mathrm{M})$ depresses WCC in a DBB neuron from C57BL/6Tac wt mice. $\boldsymbol{B}$, Application of hAmylin to a DBB neuron from Prnp ${ }^{0 / 0}$ does not result in WCC reduction. Inset shows histograms depicting hAmylin-evoked reduction of WCC at $+30 \mathrm{mV}$ in Prnp ${ }^{+/+}$(wt) and $\operatorname{Prnp}^{0 / 0}$ mice $\left.{ }^{*} p>0.001\right)$.

netic mechanism (for example, a functional polymorphism in linkage disequilibrium with the Zrch1 Prnp null allele), we also examined the effects of $\mathrm{A} \beta_{1-42}$ on DBB neurons from wt mice in the presence of a PrP antibody. For this purpose, we used the monoclonal antibody reagent Sha31. No significant reduction in WCC was identified following perfusion of DBB neurons with Sha31, thus supporting the notion that $\mathrm{A} \beta_{1-42}$ effects require $\operatorname{PrP}^{\mathrm{C}}$.

In wt mice, $\mathrm{A} \beta_{1-42}$ preparations induced a decrease in wholecell currents that was nearly abolished by iberiotoxin, a specific blocker of $I_{\mathrm{C}}$. This supports an involvement of calcium-activated potassium channels in mediating, in part, the cellular effects of $\mathrm{A} \beta_{1-42}$ on DBB neurons. $I_{\mathrm{C}}$ currents have been shown to be responsible for the repolarization phase of the action potential and, hence, play a role in the process of spike frequency adaptation (accommodation) (Vergara et al., 1998; Kim and Hoffman, 2008). The effect of $A \beta_{1-42}$ on depressing outward currents through $I_{\mathrm{C}}$ channels could result in an increased excitation of DBB neurons. Functionally, $I_{\mathrm{K}}$ channels augment action potential repolarization, and therefore $\mathrm{A} \beta_{1-42}$ reduction of $I_{\mathrm{K}}$ currents, in wt mice, would also be expected to result in an increase in the action potential width, potentially playing a role in regulation of cell excitability. Physiologically, $I_{\mathrm{A}}$ produces its effect by increasing the rate of both action potential repolarization and accommodation (Viana et al., 1993; Zhang and McBain, 1995; Gu et al., 2007). Blockage of $I_{\mathrm{A}}$ by A $\beta$ could lead to increased duration of depolarization during an action potential and consequently increase $\mathrm{Ca}^{2+}$ influx into DBB neurons. We have previously observed that $\mathrm{A} \beta$ and human amylin demonstrate identical 
electrophysiological effects on cholinergic neurons of the DBB, and moreover share a similar profile of neurotoxicity on primary cultures of neurons from this basal forebrain nucleus (Jhamandas et al., 2001, 2003; Jhamandas and MacTavish, 2004). A recent report also suggest that $\operatorname{PrP}^{\mathrm{C}}$ may also serve as a target for the expression of biological effects of amyloidogenic peptides besides $\mathrm{A} \beta$ (Resenberger et al., 2011). We therefore examined the electrophysiological effects of human amylin on DBB neurons from wt and $P r n p^{0 / 0}$ mice, where we observed that human amylin effects were markedly blunted in $\operatorname{Prnp}^{0 / 0}$ cells in a manner akin to oligomeric $\mathrm{A} \beta$. While the mechanism tying $\mathrm{A} \beta$ - or human amylin-docked $\operatorname{PrP}^{\mathrm{C}}$ to potassium conductances remains to be established, $\mathrm{A} \beta$ binding sites have been mapped to distinct $\mathrm{N}$-terminal regions within $\operatorname{PrP}^{\mathrm{C}}$ (Laurén et al., 2009; Balducci et al., 2010; Chen et al., 2010; Freir et al., 2011), but a functional effect of antibodies binding to the $\alpha$-helical C-terminal region is not without precedent. Thus ICSM18 antibody binds to helix 1 residues 146-159 (White et al., 2003) and had efficacy on hippocampal cells when administered at a concentration of $2 \mu \mathrm{g} / \mathrm{ml}$ (Freir et al., 2011), whereas Sha31 used here binds to residues 145-152 (Féraudet et al., 2005) and had efficacy on DBB cells at $0.3 \mu \mathrm{g} / \mathrm{ml}$ (Fig. $2 D$ ). These "distal" effects are compatible with the notion that PrP undergoes interactions in cis- between the flexible N-terminal region and the globular C-terminal domain (Qin et al., 2000), and clues as to how $\operatorname{PrP}^{\mathrm{C}}$ might impact potassium channels may lie within an interactome derived from the adult mouse brain (Schmitt-Ulms et al., 2004).

In addition to variable results emerging from different laboratories (see Introduction), the pro-pathogenic response of $\mathrm{PrP}^{\mathrm{C}}$ to amyloid assemblies seems at odds with neuroprotective activity. Go-forward studies to reconcile these issues will need to focus upon reliable traits present within a spectrum of phenotypically divergent TgAPP mice (Phinney et al., 2003; Ashe and Zahs, 2010; Wisniewski and Sigurdsson, 2010) and avoid the diverse effects that can be driven by different types of $\mathrm{A} \beta$ assemblies (Sakono and Zako, 2010). Divergent target cell populations under study (e.g., hippocampus vs basal forebrain) also need to be considered. When these variables are isolated, the protective and pathogenic properties of $\mathrm{PrP}^{\mathrm{C}}$ may be discerned reliably. In turn, it may be possible to test the hypothesis that pro-pathogenic effects of $\operatorname{PrP}^{\mathrm{C}}$ reflect a subverted physiological function that is poorly adapted to deal with chronic exposure to amyloid assemblies, as would be found in $\mathrm{AD}$. If the basal neuroprotective activity of $\operatorname{PrP}^{\mathrm{C}}$ can be separated in dose-response properties from pro-pathogenic effects, then $\operatorname{PrP}^{\mathrm{C}}$-directed anti-amyloid therapies may warrant closer consideration.

\section{References}

Alier K, Li Z, Mactavish D, Westaway D, Jhamandas JH (2010) Ionic mechanisms of action of prion protein fragment $\operatorname{PrP}(106-126)$ in rat basal forebrain neurons. J Neurosci Res 88:2217-2227.

Ashe KH, Zahs KR (2010) Probing the biology of Alzheimer's disease in mice. Neuron 66:631-645.

Balducci C, Beeg M, Stravalaci M, Bastone A, Sclip A, Biasini E, Tapella L, Colombo L, Manzoni C, Borsello T, Chiesa R, Gobbi M, Salmona M, Forloni G (2010) Synthetic amyloid-\{beta $\}$ oligomers impair long-term memory independently of cellular prion protein. Proc Natl Acad Sci U S A 107:2295-2300.

Barry AE, Klyubin I, Mc Donald JM, Mably AJ, Farrell MA, Scott M, Walsh DM, Rowan MJ (2011) Alzheimer's disease brain-derived amyloid- $\beta$ mediated inhibition of LTP in vivo is prevented by immunotargeting cellular prion protein. J Neurosci 31:7259-7263.

Bate C, Williams A (2011) Amyloid-\{beta\}-induced synapse damage is mediated via cross-linkage of the cellular prion protein. J Biol Chem.
Advance online publication. Retrieved September 16, 2011. doi:10.1074/jbc.M111.248724.

Bitan G, Kirkitadze MD, Lomakin A, Vollers SS, Benedek GB, Teplow DB (2003) Amyloid beta -protein (Abeta) assembly: Abeta 40 and Abeta 42 oligomerize through distinct pathways. Proc Natl Acad Sci USA 100:330-335.

Calella AM, Farinelli M, Nuvolone M, Mirante O, Moos R, Falsig J, Mansuy IM, Aguzzi A (2010) Prion protein and Abeta-related synaptic toxicity impairment. EMBO Mol Med 2:306-314.

Chen S, Yadav SP, Surewicz WK (2010) Interaction between human prion protein and amyloid-beta (Abeta) oligomers: role OF N-terminal residues. J Biol Chem 285:26377-26383.

Chishti MA, Yang DS, Janus C, Phinney AL, Horne P, Pearson J, Strome R, Zuker N, Loukides J, French J, Turner S, Lozza G, Grilli M, Kunicki S, Morissette C, Paquette J, Gervais F, Bergeron C, Fraser PE, Carlson GA, et al. (2001) Early-onset amyloid deposition and cognitive deficits in transgenic mice expressing a double mutant form of amyloid precursor protein 695. J Biol Chem 276:21562-21570.

Cissé M, Sanchez PE, Kim DH, Ho K, Yu GQ, Mucke L (2011) Ablation of cellular prion protein does not ameliorate abnormal neural network activity or cognitive dysfunction in the J20 line of human amyloid precursor protein transgenic mice. J Neurosci 31:10427-10431.

Connor JA, Stevens CF (1971) Voltage clamp studies of a transient outward membrane current in gastropod neural somata. J Physiol 213:21-30.

Féraudet C, Morel N, Simon S, Volland H, Frobert Y, Créminon C, Vilette D, Lehmann S, Grassi J (2005) Screening of 145 anti-PrP monoclonal antibodies for their capacity to inhibit PrPSc replication in infected cells. J Biol Chem 280:11247-11258.

Freir DB, Nicoll AJ, Klyubin I, Panico S, Mc Donald JM, Risse E, Asante EA, Farrow MA, Sessions RB, Saibil HR, Clarke AR, Rowan MJ, Walsh DM, Collinge J (2011) Interaction between prion protein and toxic amyloid beta assemblies can be therapeutically targeted at multiple sites. Nat Commun 2:336.

Gimbel DA, Nygaard HB, Coffey EE, Gunther EC, Laurén J, Gimbel ZA, Strittmatter SM (2010) Memory impairment in transgenic Alzheimer mice requires cellular prion protein. J Neurosci 30:6367-6374.

Gu N, Vervaeke K, Storm JF (2007) BK potassium channels facilitate highfrequency firing and cause early spike frequency adaptation in rat CA1 hippocampal pyramidal cells. J Physiol 580:859-882.

Janus C, Pearson J, McLaurin J, Mathews PM, Jiang Y, Schmidt SD, Chishti MA, Horne P, Heslin D, French J, Mount HT, Nixon RA, Mercken M, Bergeron C, Fraser PE, St George-Hyslop P, Westaway D (2000) A beta peptide immunization reduces behavioural impairment and plaques in a model of Alzheimer's disease. Nature 408:979-982.

Jassar BS, Harris KH, Ostashewski PM, Jhamandas JH (1999) Ionic mechanisms of action of neurotensin in acutely dissociated neurons from the diagonal band of Broca of the rat. J Neurophysiol 81:234-246.

Jhamandas JH, MacTavish D (2004) Antagonist of the amylin receptor blocks $\beta$-amyloid toxicity in rat cholinergic basal forebrain neurons. J Neurosci 24:5579-5584.

Jhamandas JH, Cho C, Jassar B, Harris K, MacTavish D, Easaw J (2001) Cellular mechanisms for amyloid beta-protein activation of rat cholinergic basal forebrain neurons. J Neurophysiol 86:1312-1320.

Jhamandas JH, Harris KH, Cho C, Fu W, MacTavish D (2003) Human amylin actions on rat cholinergic basal forebrain neurons: antagonism of beta-amyloid effects. J Neurophysiol 89:2923-2930.

Jhamandas JH, Wie MB, Harris K, MacTavish D, Kar S (2005) Fucoidan inhibits cellular and neurotoxic effects of beta-amyloid (A beta) in rat cholinergic basal forebrain neurons. Eur J Neurosci 21:2649-2659.

Jhamandas JH, Li Z, Westaway D, Yang J, Jassar S, MacTavish D (2011) Actions of beta-amyloid protein on human neurons are expressed through the amylin receptor. Am J Pathol 178:140-149.

Kessels HW, Nguyen LN, Nabavi S, Malinow R (2010) The prion protein as a receptor for amyloid-beta. Nature 466:E3-E4; discussion E4-E5.

Kim J, Hoffman DA (2008) Potassium channels: newly found players in synaptic plasticity. Neuroscientist 14:276-286.

Kirkitadze MD, Kowalska A (2005) Molecular mechanisms initiating amyloid beta-fibril formation in Alzheimer's disease. Acta Biochim Pol 52:417-423.

Laurén J, Gimbel DA, Nygaard HB, Gilbert JW, Strittmatter SM (2009) Cellular prion protein mediates impairment of synaptic plasticity by amyloid-beta oligomers. Nature 457:1128-1132. 
Palop JJ, Mucke L (2010) Amyloid-beta-induced neuronal dysfunction in Alzheimer's disease: from synapses toward neural networks. Nat Neurosci $13: 812-818$

Phinney AL, Horne P, Yang J, Janus C, Bergeron C, Westaway D (2003) Mouse models of Alzheimer's disease: the long and filamentous road. Neurol Res 25:590-600.

Prusiner SB (1991) Molecular biology of prion diseases. Science 252:1515-1522.

Qin K, Yang DS, Yang Y, Chishti MA, Meng LJ, Kretzschmar HA, Yip CM, Fraser PE, Westaway D (2000) Copper(II)-induced conformational changes and protease resistance in recombinant and cellular PrP. Effect of protein age and deamidation. J Biol Chem 275:19121-19131.

Resenberger UK, Harmeier A, Woerner AC, Goodman JL, Müller V, Krishnan R, Vabulas RM, Kretzschmar HA, Lindquist S, Hartl FU, Multhaup G, Winklhofer KF, Tatzelt J (2011) The cellular prion protein mediates neurotoxic signalling of beta-sheet-rich conformers independent of prion replication. EMBO J 30:2057-2070.

Sakono M, Zako T (2010) Amyloid oligomers: formation and toxicity of Abeta oligomers. FEBS J 277:1348-1358.

Schmitt-Ulms G, Hansen K, Liu J, Cowdrey C, Yang J, DeArmond SJ, Cohen FE, Prusiner SB, Baldwin MA (2004) Time-controlled transcardiac perfusion cross-linking for the study of protein interactions in complex tissues. Nat Biotechnol 22:724-731.

Stine WB Jr, Dahlgren KN, Krafft GA, LaDu MJ (2003) In vitro characterization of conditions for amyloid-beta peptide oligomerization and fibrillogenesis. J Biol Chem 278:11612-11622.
Stine WB, Jungbauer L, Yu C, LaDu MJ (2011) Preparing synthetic Abeta in different aggregation states. Methods Mol Biol 670:13-32.

Teplow DB, Lazo ND, Bitan G, Bernstein S, Wyttenbach T, Bowers MT, Baumketner A, Shea JE, Urbanc B, Cruz L, Borreguero J, Stanley HE (2006) Elucidating amyloid beta-protein folding and assembly: a multidisciplinary approach. Acc Chem Res 39:635-645.

Vergara C, Latorre R, Marrion NV, Adelman JP (1998) Calcium-activated potassium channels. Curr Opin Neurobiol 8:321-329.

Viana F, Bayliss DA, Berger AJ (1993) Multiple potassium conductances and their role in action potential repolarization and repetitive firing behavior of neonatal rat hypoglossal motoneurons. J Neurophysiol 69:2150-2163.

Walsh DM, Klyubin I, Fadeeva JV, Cullen WK, Anwyl R, Wolfe MS, Rowan MJ, Selkoe DJ (2002) Naturally secreted oligomers of amyloid beta protein potently inhibit hippocampal long-term potentiation in vivo. Nature 416:535-539.

White AR, Enever P, Tayebi M, Mushens R, Linehan J, Brandner S, Anstee D, Collinge J, Hawke S (2003) Monoclonal antibodies inhibit prion replication and delay the development of prion disease. Nature 422:80-83.

Wisniewski T, Sigurdsson EM (2010) Murine models of Alzheimer's disease and their use in developing immunotherapies. Biochim Biophys Acta 1802:847-859.

Zhang L, McBain CJ (1995) Potassium conductances underlying repolarization and after-hyperpolarization in rat CA1 hippocampal interneurones. J Physiol 488:661-672. 